\title{
THE IMPACT OF PROCEDURE-IMPACT STUDIES IN THE ADMINISTRATION OF JUSTICE
}

\author{
MAUrice RosenberG*
}

\section{INTRODUCTION}

Empirical research on the functioning of procedural rules has had a slowly growing impact on the litigation process. At times the findings produced by this research have influenced legislators and rulemakers to make changes in their codes of procedure. At other times the findings have led judges to accept or reject a rule. Regrettably, the examples of such impacts have not been numerous. In part this lack of influence is due to the unreceptiveness of the intended users. Many lawyers and judges appear to believe that thinking like a lawyer means relying on law books, logic, speculation, argument, andwhen it comes to addressing questions of societal reality-invoking intuition. They act as if Holmes' epigram about the life of the law being "experience" should be understood to refer to the random experience of the individual jurist. Not in my book. I believe Holmes was referring to the collective experience of the relevant societal constituency and that he would have required that this experience be tapped by the most feasible systematic means.

That this interpretation is not more widely accepted suggests that we are face-to-face with an old truth: Lawyers are suspicious or fearful or both when they confront the methods and findings of the social sciences. This attitude is seriously shortsighted. More than twenty years ago the President's Commission on Law Enforcement and the Administration of Justice warned that speculation and intuition are inadequate instruments with which to solve all the problems law addresses. Its final report declared: "The commission has found and discussed throughout this report many needs of law enforcement and the administration of criminal justice. But what it has found to be the greatest need is the need to know."'

In the administration of civil justice the need to know is not less urgent than in criminal justice. What is more, the civil need can often be satisfied with much certainty, for rules of civil procedure are generally designed to

\footnotetext{
Copyright (C) 1988 by Law and Contemporary Problems

* Harold R. Medina Professor of Procedural Jurisprudence, Columbia University School of Law.

1. The Challenge of Crime in a Free Society: A Report by the President's Commission on LaW Enforcement and Administration of Justice 273 (1967).
} 
serve practical ends such as efficiency, dispatch, and economy-qualities that are relatively susceptible to systematic measurement. To know the impact of a rule of civil procedure requires answering but two straightforward questions: Does the rule work? Does it achieve the intended results without unacceptable side effects?

Producing dependable answers to these simply stated questions turns out to be no sport for a novice. The problems of methodology can be especially baffling to a law-trained researcher, who may suppose the impact of a new rule can be derived best by comparing the careers of cases before and after the rule change occurred. But no procedural rule operates in a vacuum. It is embedded in a constellation of facts and influences that make isolating the impact of the particular rule a complex task. One must exclude "plausible rival hypotheses"'2 and control for "threats to validity"3 before concluding that the rule in question produced an observed change. No design can totally eliminate all competing hypotheses, but some designs are better than others. Without doubt, the most powerful and reliable way to investigate the impact of a legal rule, procedure, program, or other intervention is to conduct a controlled experiment. ${ }^{4}$ The strength of this method lies in its ability to isolate the impact of the legal intervention under investigation by excluding all other factors that may account for the observed effects or relationships. The strength of this method lies in its ability to isolate the impact of the legal intervention under investigation by excluding all other factors that may account for the observed effects or relationships.

EXPERIMENTS IN THE LAW

As lawmakers increasingly confront the "need to know" before they enact new laws or amend existing ones, they look more and more to the natural sciences to borrow the most powerful available methods of research. ${ }^{5}$ This leads them inevitably to the controlled experiment, with random assignment of subjects, a research method par excellence in science. Many respected scholars and officials are convinced that this type of controlled experiment is the best method of acquiring knowledge about the impact of legal rules or programs. ${ }^{6}$ There is much reluctance, however, to utilize experimental methods in sociological research because of misgivings on constitutional grounds and growing sensitivity on ethical grounds. ${ }^{7}$ A pervasive objection is that experimentation requires assigning human subjects randomly to one or another treatment group regardless of differences among the subjects, in

2. Campbell, Reforms As Experiments, 24 Aм. Psychologist 409, 411 (1969).

3. Lempert, Strategies of Research Design in the Legal Impact Study, I.Aw. \& Soc'y Rev., Nov. 1966. at $111,112-18$.

4. See Experimentation in the Iaw: Report of the federal Judicial Center Advisori Committee on EXPerimentation IN THE LAW 16-19 (1981).

5. Id. at 2 .

6. Id. at 16-19.

7. Id. at 5-6. 
violation of the tenet that a person should be treated according to his or her individual circumstances rather than according to the luck of the draw in a lottery. ${ }^{8}$

Reservations about the controlled experiment pose a serious dilemma for improvement of the law. While responsible lawmakers do not want to use procedures that have ethical or constitutional defects, outright rejection of controlled experimentation means giving up a powerful instrument of research and seriously reducing the chance of gaining knowledge about law in action. Those considerations compel us to look carefully at the implications of either too free or too restrictive a view of the propriety of experimentation in legal settings.

Of course, no one should pretend that the impact of new legal programs and new rules can be gauged only by experimentation or other sophisticated and elaborate methods of inquiry. Obviously, some changes in the law have such clear consequences that personal observation and common sense can make them known without rigorous research. Even unsystematically gathered experience teaches much. We know, for example, that when the grounds for divorce are made easier and broader more divorces are sought and obtained. When a highly publicized program of towing illegally parked cars goes into effect, more cars park lawfully. The repeal of Prohibition was followed, not coincidentally, by a decline in bootlegging. Countless similar examples could be listed.

But the consequence of a change in the legal rule or program is not always clear. Usually the change is much less dramatic than in the examples cited; and often other changes are introduced at the same time, throwing doubt on which of the factors was the effective one. For instance, if the state's lawmakers wanted to know whether introduction of no-fault automobile injury insurance reduced the volume of suits filed, they would probably find that some other legal or social factor changed at about the time the shift was made to no-fault. The comparative negligence doctrine may have replaced contributory negligence, or new rules of liability and damages may have taken hold. Effects of the no-fault change are clouded by the unknown effects of the changes in the negligence and damage rules.

That problem brings us to the other horn of the dilemma. When substitutes for the controlled experiment are used, serious risks to the reliability of the findings arise. Besides the problem that contemporaneous changes other than the one under investigation may confound the findings (the "historical" threat), validity threats going by the names "maturation," "experimental mortality," "testing," and so on, may obscure the results. These are highly resistant to control in a satisfactory way except by experimental methods. The result is that there is heavy pressure to use the experimental method to overcome ambiguities and doubts of the type that

8. Id. at 26 . 
less powerful research methods cannot eliminate. But doing so puts us back on the other horn of the dilemma.

In addition, the experimental model is not wholly adaptable to the law's needs. First, there is the fact that in sociolegal contexts human subjects are inevitably and irreplaceably involved. Their presence gives rise to legal or ethical problems that are far more difficult than those the natural sciences ordinarily face when using inanimate materials. Furthermore, experimental controls are hard to impose in the complex, ever-changing environment of modern society. Finally, above all other problems is the autonomous quality of human behavior. Unlike chemical elements, heavenly bodies, or bacteria, and regardless of how predictable their actions may be en masse, individual humans can go their separate ways for any reason or no reason whatever. Atoms, molecules-even muscles, lungs, and hearts-are more disciplined and dependable in their reactions to stimuli.

One consequence of these facts is that the reliability of evidence obtained from sociological research often depends less upon the quality of the conceptualization and methodology of the research than upon the particular subject matter and surrounding circumstances. An additional obstacle to putting research to practical use in sociolegal contexts is the fact that the costs of error can be serious and widespread. Faced with such grave risks and problems, many lawmakers and scholars recoil from even attempting to gain information through empirical research.

\section{III}

\section{The Problem of Equal Protection of the Law}

The equal protection principle requires that persons subjected to significantly different treatments must be shown to be different in ways that supply a reasonable basis for the differences in treatment. ${ }^{9}$ By contrast, the experimental model requires that subjects exposed to different treatments be selected randomly, not designedly or for particular reasons. In other words, to use the experimental design is to abandon any thought of justifying the different treatment accorded one subject as against another on the basis of reasons that are related particularly to the subject. In what way, then, may unequal treatment of similarly situated persons be justified? Is the need to know a sufficient reason? In a case involving state-established experimental work programs for welfare recipients, the late Judge Henry J. Friendly answered in the affirmative, using as the test whether "an appropriate governmental interest [is] suitably furthered by the differential treatment."10

In the real world in which law operates, it is impossible to carry on investigations under perfect experimental conditions. Official governmental

9. Lehr v. Robertson, 463 U.S. 248,269 n.27 (1983); Weber v. Aetna Casualty \& Sur. Co., 406 U.S. 164, 172 (1972); Rinaldi v. Yeager, 384 U.S. 305, 309 (1966).

10. See Aguayo v. Richardson, 473 F.2d 1090, 1109 (2d Cir. 1973) (quoting Justice Marshall in Chicago Police Dep't v. Mosely, 408 U.S. 92, 95 (1972)). 
support can help investigators approach the ideal. The key is to persuade the authorities that the projected research will be lawful, ethical, and productive. If permitted, experimental research can provide uniquely informative results. Other law-related empirical research designs attempt to achieve the power of the experimental paradigm by seeking in various ways to isolate and control for the impact of the legal intervention under study. Even though measuring impact by survey research and other second-best methods cannot produce findings as trustworthy as those that come from experimental methods, the results can be useful and of significant help. The remainder of this paper assesses: (1) several leading examples of experimental research on procedures in civil litigation; (2) examples of noteworthy nonexperimental research on important civil practice rules; and (3) an example of use by a court of impact research findings in the context of judicial administration.

\section{IV}

\section{The New Jersey Pretrial Conference Experiment}

Of the controlled official experiments that are credited with significant impacts on the administration of justice in civil litigation, the most elaborate was the investigation in New Jersey in 1960-62 of the effects of mandatory pretrial conferences on the court careers of personal injury cases." The research was conducted by the Columbia Project for Effective Justice. ${ }^{12}$ A major purpose was to determine whether mandatory pretrial conferences reduced the time required for the courts to process and dispose of personal injury cases. ${ }^{13}$

In order to put the experiment into effect, the New Jersey Supreme Court, in 1959, suspended its rule commanding that all personal injury cases go through a pretrial conference. Instead, for six months starting January 4, 1960 , in about half the state's general jurisdiction trial courts every second case was not scheduled for a mandatory pretrial conference and was simply set for trial. A conference was held, however, in those cases if either or both lawyers requested one. The nonmandatory alternate cases were to serve as a control group. During the course of the experiment, a total of 3000 cases passed through the program. By the end of 1962 the cases had run their courses, either producing a settlement or reaching trial-and in a few instances proceeding beyond the judgment to an appeal. By means of detailed follow-up investigation, a mass of information was obtained from the judges, lawyers, and clerks concerned with the cases. ${ }^{14}$

The Columbia investigators' original hope had been to withhold a pretrial conference from all the alternate cases, so that half the 3000 cases would have gone through the judicial process without having been exposed to the

11. See M. Rosenberg, The Pretrial Conference and Effective Justice $28-70$ (1964) (data were assembled and analyzed).

12. Id. at 2. The author directed the Columbia Project from its start in 1956 until 1964.

13. Id. at 24-25.

14. Id. at $18-20$. 
conference procedure. However, the justices of the New Jersey Supreme Court were unwilling to install the proposed ideal experimental design, apparently out of concern for possible criticism on equal protection grounds. In exercising their rulemaking power, the justices would go no further than to provide that if a case fell by chance into the nonmandatory group, the opposing lawyers in the case could choose that the case nonetheless undergo a pretrial conference. The Columbia research team agreed to the modified design in the expectation that few lawyers would opt for a pretrial conference. As it turned out, in half the cases not scheduled for a mandatory conference one or both sides elected to have an optional conference. ${ }^{15}$ This compromised the scientific rigor of the controlled experiment, but still permitted a valid comparison of the impact of a mandatory pretrial conference program for personal injury cases with an optional regime; and since the pretrial conference was the only different procedure in the two groups of cases, the researchers were satisfied that observed differences could properly be attributed to the existence or absence of a pretrial conference in the cases.

At the end of the experiment it was possible to compare what happened to suits that went to mandatory conference with the litigation career and outcome of suits exposed to optional conference processing. The comparisons concerned three main variables. The first was whether the mandatory conference procedure increased the courts' efficiency by reducing outlays of judges' time. ${ }^{16}$ Another was whether the mandatory conference program made any difference in the quality of the proceedings that followed it. ${ }^{17}$ Did a conference observably improve the quality of the trial? That led to the question of how one determines whether one process is of better quality than another. The legal literature revealed virtually nothing on this subject. Even Cardozo's The Nature of the Judicial Process ${ }^{18}$ makes no mention of the characteristics or indicators of a quality process. It was necessary to devise and apply homemade quality-of-process criteria. Four sets of indicators were chosen: whether the issues were presented clearly and fully at the trial; whether there were gaps or redundancies in the evidence; whether the lawyers seemed to be well prepared according to the reports of the trial judge and the trial lawyers themselves; and whether there was tactical surprise on the part of either side. ${ }^{19}$ Evaluating the impact of procedural reforms today, I would suggest adding another process-quality indicator: whether the process retains the human touch or becomes excessively mechanical and oriented toward assembly-line production.

15. There was anecdotal evidence that a major reason for the unexpectedly high rate of acceptance of optional pretrial conference was the defendants' lawyers' interest in earning the fees paid attorneys for taking part in such conferences.

16. M. Rosenberg, supra note 11 , at $28,45-58$.

17. Id. at $28-44$.

18. B. Cardozo, The Nature of the Judicial Process (1921).

19. M. Rosenberg, supra note 11 , at 30 . 
In the end the experiment produced not two but three major findings. ${ }^{20}$ First, on the question of efficiency, the data showed that the mandatory pretrial conference procedure did not save judicial time: In the mandatory program about 24 percent of the cases reached trial, and in the nonmandatory set about 22 percent reached trial. ${ }^{21}$ These figures are strong evidence that the pretrial conference did not produce a significant difference in the trialreaching propensity of the cases. The length of trials in the mandatorily pretried and the optional sets of cases was likewise about equal. ${ }^{22}$ Considering the large number of cases and the design, we concluded with confidence that there was no saving of trials or trial time under the mandatory pretrial conference rule. The time used by the judges in pretrial conference resulted neither in eliminating trials that would otherwise have been necessary nor in shortening trials that had to be conducted. Thus we were satisfied that the mandatory procedure did not succeed in enhancing judicial efficiency.

On the quality side, there was a clear edge in favor of the group of cases exposed to mandatory pretrial conferences. From the responses of the lawyers and judges who participated at the trial, it appeared that in the mandatorily pretried set of cases there were higher scores on quality indicia than in the group of cases in which a pretrial conference was optional. These scores did not produce statistically significant differences when evaluated one factor at a time, but when the quality indicia were combined-"collapsed," in statistical terminology-they registered significant differences in favor of the mandatorily pretried group of cases. ${ }^{23}$ This led us to conclude that in practice the pretrial conference had a substantial positive impact on process quality.

A third finding was unexpected: Plaintiffs recovered more money in the mandatorily pretried group. When amounts paid to plaintiffs after settlements and judgments were totaled, the mandatorily pretried cases produced about 20 percent more dollars for plaintiffs than the cases in the optional pretrial group. ${ }^{24}$ The data did not reveal any evident explanation for this result. ${ }^{25}$

When these findings were reported to the Supreme Court of New Jersey, the court used its rulemaking power to replace the mandatory pretrial conference rule with an optional rule in personal injury cases arising from motor vehicle accidents. ${ }^{26}$ Since these were by far the largest category of relevant lawsuits, the impact was substantial.

\footnotetext{
20. Id. at 28 .

21. Id. at $45-58$.

22. Id. at $46-47$.

23. Id. at $28-44$.

24. Id. at 58-67.

25. A possible explanation is that the disclosure of positions and evidence at the pretrial conference is more beneficial to plaintiffs' counsel than to defendants'. The latter are likely to have a high volume of personal injury retainers for insurance companies; the former tend to be only occasional litigators. Perhaps the pretrial conference aids the occasional advocate more than the experienced one.

26. N.J. Super. Ct. Rule 4:29-1 (a) (1988) (formerly Rule 4:25-1 (a); amended July 7, 1971).
} 


\section{$\mathrm{V}$ \\ The Ontario Experiment with Pretrial Conferences}

A useful counterpoint to the New Jersey experiment exists. In 1975 the Canadian province of Ontario introduced pretrial conferences and began regular use of them in civil jury cases in Toronto. ${ }^{27}$ Initial favorable reactions of the bar suggested the desirability of extending the procedure to non-jury cases. To evaluate the impact the Supreme Court of Ontario installed an experimental research program. As with the New Jersey plan, the design called for requiring a pretrial conference in half the non-jury cases and using the other half as a control group. A research team evaluated the results on the basis of answers to a set of questions patterned on the forms and questions employed by the Columbia project in New Jersey, except that quality-of-process indicators were omitted. In 1977 the authors published a report announcing tentative findings. ${ }^{28}$

In 1984 Professor Garry D. Watson delivered an address in which he reported that utilizing pretrial conferences increased settlement rates by 10 percent. ${ }^{29}$ Another finding was that cases involving moderate stakes are easier to settle than those with small or very large sums in dispute. ${ }^{30}$ Calling attention to the discrepant findings, Professor Watson's address identified substantial differences in the New Jersey and Ontario cases, judges, and procedures, including the following: the purpose of the Ontario pretrial conference was to try to achieve settlement (not to prepare the case for trial); the Ontario cases were of mixed types (not exclusively personal injury); only eleven handpicked pretrial-favoring Ontario judges participated (compared to forty-nine New Jersey judges with varied attitudes toward the procedure); only non-jury cases were involved (in contrast to the all-jury-bound cases in New Jersey); and the innovation in Ontario was requiring a pretrial conference rather than dispensing with it. ${ }^{31}$

\section{VI}

\section{The CamP Experiment in the Second Circuit}

Starting in 1974, the United States Court of Appeals for the Second Circuit conducted an official controlled experiment to evaluate the Civil Appeals Management Plan ("CAMP"). ${ }^{32}$ The goal of the experiment was to assess the impact of the court's rule requiring that in civil appeals coming within the CAMP program's specifications (1) a "scheduling order" be issued

27. See Stevenson, Watson \& Weissman, The Impact of Pretrial Conferences: An Interim Report on the Ontario Pretrial Conference Experiment, 15 Oscoode Hall L.J. 591, 591 (1977).

28. Id. So far as can be learned, no final statement has been published reporting the results in Ontario.

29. G. Watson, Judicial Mediation: The Results of a Controlled Experiment in the Use of Settlement-Oriented Pretrial Conferences at i, 7 (preliminary draft June 1984) (delivered at the Annual Meeting of the Law and Society Association).

30. Id. at 11 .

31. Id. at 15-17.

32. A. Lind \& A. Partridge, A Reevaluation of the Civil Appeals Management Plan (1983). 
at the outset, fixing deadlines for the filing of briefs, oral argument, and other significant events in the course of the appeal; and (2) a preargument conference be held. ${ }^{33}$

The aims of CAMP were to expedite and improve the appellate process by eliminating appeals that either would go off the calendar as a result of a firm set of scheduled deadlines or that would settle at a preargument conference, and to improve the quality of appeals that require decision by the court. ${ }^{34} \mathrm{At}$ first one senior staff attorney managed and operated all aspects of the program, without any judicial participation. ${ }^{35}$ Later, a second attorney was added. ${ }^{36}$

CAMP was installed with financial support from the Federal Judicial Center on condition that the Center make an evaluation of the procedure by means of a controlled experiment. For the term of the experiment, appeals deemed eligible for CAMP procedures were to be randomly assigned either to the experimental group or to a control group. ${ }^{37}$ The former cases received the CAMP process, whereas cases in the control group did not and were permitted to proceed toward resolution without any unusual processing. ${ }^{38}$

Then chief judge of the court, Irving R. Kaufman, named a committee to work with the circuit executive to monitor the controlled experiment. The committee consisted of a Columbia professor of social science, a practicing lawyer, and the author. ${ }^{39}$ As the program was designed, every fourth case randomly selected from the CAMP-eligible categories would bypass the scheduling and conference procedure, remaining on the court's docket and proceeding as in pre-CAMP days. At the end of the experimental period, 450 appeals had been processed in the program, with a fourth of them serving as the control group. ${ }^{40}$

The results of the program were that the CAMP-processed appeals terminated more rapidly than those in the control group and required less judicial time. They produced a higher proportion of settlements, thus reducing the fraction of appeals in which the court was obliged to hear argument and render decision. Compared to the CAMP-processed experimental cases, the control cases were found to require the full process of briefing, argument, and judicial decision 20 percent more frequently. The reduced rate of arguments and decisions for the CAMP-processed appeals translated into an estimated saving of two judgeships, at that time costing about $\$ 400,000$ a year.

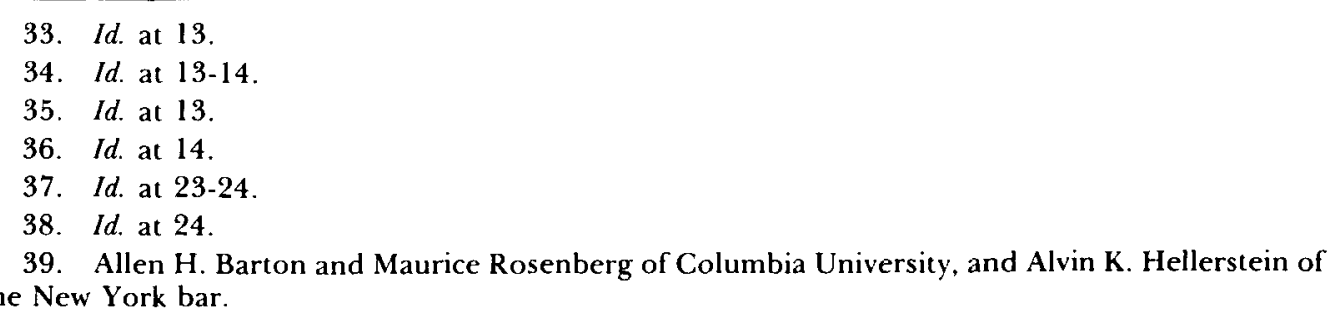

40. A. Lind \& A. Partridge, supra note 32 , at 3. 
Citing the findings, the Second Circuit Court of Appeals made the CAMP program permanent. In 1983, following its own analysis of the data produced by the experimental program, the Federal Judicial Center published an evaluation of the CAMP experiment, concluding that:

[T] he data from the present experiment offer persuasive evidence that the Civil Appeals Management Plan reduces the number of appeals that reach argument. The best single estimate is that the program diverts from the argument stream about 10 percent of the appeals filed that are eligible for CAMP treatment, or about 16 percent of such appeals that would reach argument in the absence of the program. ${ }^{41}$

Five other circuits and several state appellate courts have adopted similar programs. ${ }^{42}$ The six federal circuits that have the preargument conference program, with the year their program began, are as follows: Second (1974); Third (1984); Sixth (1981); Eighth (1981); Ninth (1982); and D.C. (1987). ${ }^{43}$

\section{VII}

\section{Civil Caseflow-Management Experiment in Kentucky}

Early in this decade delay and costs of litigation were on the rise in Kentucky courts. In an effort to check them, Kentucky Chief Justice John S. Palmore introduced an experiment with a case-management system which gave two presiding judges control of the pace and procedures in civil cases on the court's docket. ${ }^{44}$ The Circuit Court in Campbell County was selected as the site for testing the new system. The program was experimental both in the sense of serving as a tryout for the case-management system and in the sense of involving a controlled application of the experimental variable. In a group of randomly chosen cases, the court used the new system. In the rest of the cases existing procedures were applied, providing a control group. ${ }^{45}$

A clerk reviewed the complaint in each filed case to determine whether it fell into one of the five categories eligible for the special experimental casemanagement docket: contract, personal injury, property damage, property rights, and termination of parental rights. From the pool thus created one half of the incoming cases were subjected to the experimental procedures and the other half to the traditional procedures. Cases were selected for one or the other type of processing by random drawing from a deck consisting of 100 cards, one half marked for experimental treatment and the other half for treatment as a control group. The cards were then evenly divided between the two judges participating in the experiment. Cases thus were equally distributed between both dockets and both judges. Experimental cases went to the special docket, where they were dealt with under the new procedures;

41. Id. at 6 .

42. See Generous \& Knocke, "CAMP'ing is on the Rise: A Survey of Judicially-Implemented PreArgument Conference Programs in the United States Circuit Courts of Appeal, 1987 Mo. J. Dispute Resolution 89.

43. Id. 11.

44. Connolly \& Planet, Controlling the Caseflow-Kentucky Style, 21 Judges' J., Fall 1982, at 8, 10 -

45. Id. at 11 . 
control cases were assigned to the regular pool and followed the regular procedures.

The experimental program called for early and continuous calendar control of the cases; precise deadlines for major procedural stages, with provision for flexibility where necessary; a discovery conference when the case reached the at-issue stage; restricted discovery; and a pretrial conference. ${ }^{46}$ None of those procedures was followed in the control cases. An independent outside entity set up a research program to determine what impact the new case-management rules had on: (1) time required to dispose of cases; (2) costs of litigation to the courts and the litigants; (3) and the quality of justice in the cases processed. ${ }^{47}$ In 1982 the researchers reported that the program was operating successfully after eighteen months. ${ }^{48}$ Case processing time was shortened to five months (a reduction of eleven months). Some cases closed at earlier stages: 18 percent more experimentally processed cases closed before joinder of issue and 16 percent more during discovery. ${ }^{49}$ However, the overall proportion of settled and adjudicated cases was nearly identical. ${ }^{50}$ Most lawyers reported spending less time on the experimentally processed cases. ${ }^{51}$ The quality of dispositions was not adversely affected. ${ }^{2}$ Despite its apparent early success, for whatever reasons, the Kentucky program did not spread beyond Kentucky.

\section{VIII}

\section{PAC's Court-Annexed Arbitration Experiment}

Another official controlled experiment that may have a significant impact on the administration of justice is in its final phase at the Private Adjudication Center, Inc. ("PAC"), an affiliate of the Duke University School of Law. The experiment seeks to learn the impact of the court-annexed arbitration process installed by the United States District Court for the Middle District of North Carolina on January 1, 1985. Pursuant to a local rule of the court, cases were referred to the PAC for an arbitration hearing, with the parties given the option to return to the court stream afterward if dissatisfied with the results. ${ }^{53}$

A growing number of state and federal courts (in all, about thirty at this time) have adopted programs calling for mandatory referral of designated types of civil actions to volunteer arbitrators for hearing and award unless a settlement is reached at an earlier date. ${ }^{54}$ These programs differ in various ways, but have in common a number of features. First, the arbitration process

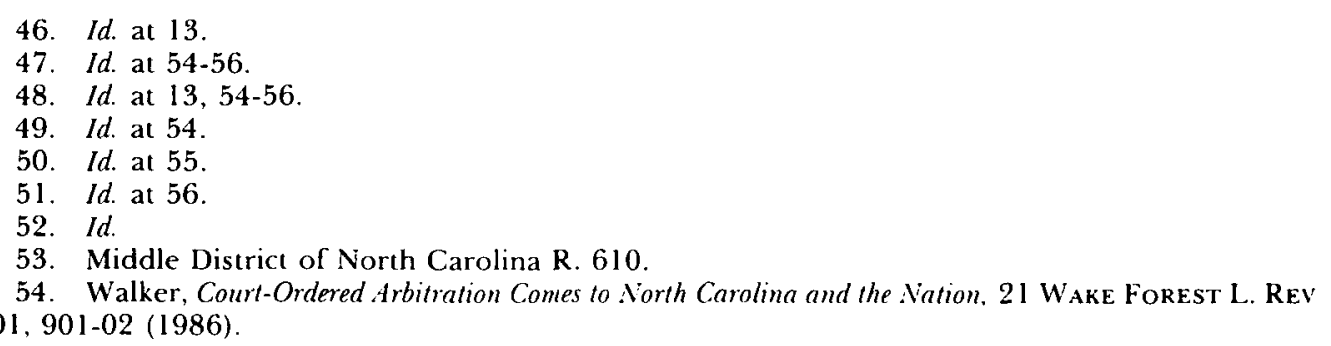


is generally required only when the action is one for damages within a specified monetary limit. ${ }^{55}$ Second, the arbitrators are volunteers who are paid small honoraria. ${ }^{56}$ Third, the hearings are conducted informally, with relaxed rules of evidence. ${ }^{57}$ Fourth, after an award is made, if the verdict is accepted by the parties, it is entered as a judgment of the court and is legally enforceable. ${ }^{58}$ If either side rejects the award, the case returns to the regular trial calendar and is heard de novo without any reference to the arbitration. ${ }^{59}$ The monetary limit of $\$ 150,000$ in the Middle District of North Carolina is the highest in the nation. ${ }^{60}$

Court-annexed mandatory non-binding arbitration has several purposes: to reduce delay on the civil trial calendar; to provide litigants with an opportunity for speedy and convenient adjudication of their disputes; and to reduce litigation costs. ${ }^{61}$ The questions investigated by the PAC were whether these purposes were achieved and, if so, to what extent. ${ }^{62}$ The design of the experiment called for a control group of one-fourth of the cases selected for arbitration. After an initial period in which nearly all eligible cases were sent to arbitration, the project made a random allocation of one case in four to establish a control group. Cases in this group proceeded to termination on the regular court docket.

At this writing, only preliminary results have been obtained. ${ }^{63}$ They do not definitely indicate whether the arbitration program expedites case termination. ${ }^{64}$ They do show that hearings before arbitrators were of substantial length, averaging over eight hours. ${ }^{65}$ Participants-litigants as well as lawyers-have reported high levels of satisfaction with both the arbitrators and the process in the PAC program. ${ }^{66}$ That finding parallels the results of a number of studies completed by various groups since courtannexed arbitration was first used. ${ }^{67}$ Although a high rate of demand for trial de novo (70 percent) was experienced in the first two years of the PAC program, on the basis of observations in other court-annexed arbitration

55. Id. at $918-19$.

56. Id. at 925 .

57. Id. at $928-30$.

58. Id. at 931 .

59. Id. at 936 .

60. Id. at 919 .

61. See id. at 902-04. See also E. Lind, Status Report to the Court: Current Findings of Research on the Program for Court-Annexed Arbitration in the Middle District of North Carolina (unpublished interim report Jan. 28, 1987).

62. E. Lind, supra note 61 .

63. Id.

64. Id. at 1-5

65. Id. at 1 .

66. Id. at $1,6-9$.

67. See A. Lind \& J. Shapard, Evaluation of Court-Annexed Arbitration in Three Federal District Courts 92-94 (1983); Hensler, What We Know and Don't Know About Court-Annexed Arbitration. 69 Judicature 270, 275 (1986); Walker, supra note 54, at 914-17, 940; Levin, Court-.tnneved Arbitration, 16 U. Mich. J. L. ReF. 537, 547 (1983); Rosenberg \& Schubin, Trial by Lawyer: Compulsory Arbitration of Small Claims in Pennsylvania, 74 HARv. L. REv. 448, 466-71 (1961). 
programs, relatively few of these demands are likely to produce actual trials. ${ }^{68}$ As to expenses, incomplete results from the PAC project suggest that arbitration reduced the litigants' costs. ${ }^{69}$

Over the years a great many attempts have been made to assess the impact of court-annexed arbitration programs. In the past none of these yielded reliable answers because of uncertainty regarding such questions as how many trials and how much expense would have resulted if the cases had not been sent to arbitration. The PAC's experimental program should provide dependable and convincing data on those impact issues as well as others.

A recent report on the results of the first two years of an experimental program in the state courts of North Carolina replicates the PAC's tentative findings regarding user satisfaction and reduced court burdens. ${ }^{70}$

\section{IX}

\section{Non-experimental Research: Rule 16 of the Federal Rules of Givil Procedure}

In 1983 the federal pretrial conference rule, Rule 16, was substantially amended to take account of changes in the way federal litigation is conducted today compared with fifty years ago when the Federal Rules were originally promulgated. In proposing the Rule's amendments, the Advisory Committee on the Federal Civil Rules was explicit about its reliance on empirical studies that assessed the impact of the judge's intervention early in the action:

Given the significant changes in federal civil litigation since $1938 \ldots$ Rule $16 \ldots$ has been extensively rewritten and expanded to meet the challenges of modern litigation. Empirical studies reveal that when a trial judge intervenes personally at an early stage to assume judicial control over a case and to schedule dates for completion by the parties of the principal pretrial steps, the case is disposed of by settlement or trial more efficiently and with less cost and delay than when the parties are left to their own devices. Flanders, Case Management and Court Management in United States District Courts 17, Federal Judicial Center (1977). Thus, the rule mandates a pretrial scheduling order. . . . ${ }^{71}$

This use by a federal advisory committee of the results of empirical research as a basis for procedural rulemaking is an example of a significant trend in improving the administration of justice.

To date, the most extensive use of this kind was in connection with the 1970 amendments to the Federal Rules governing pretrial discovery. In the 1960's the Advisory Committee, chaired by Dean Acheson, with Professors Benjamin Kaplan and Albert M. Sacks of the Harvard Law School as reporters, asked the Columbia Project for Effective Justice to do a field survey of the federal discovery rules. The general aim was to learn what, if any, differences would appear from examining discovery in action, instead of

68. See, e.g., Hensler, supra note 67 , at 274 .

69. This conclusion would be consistent with findings about similar arbitration programs in California and Pittsburgh. See Hensler, supra note 67.

70. Court-Ordered Arbitration: Report to the Supreme Court of North Carolina by the North Carolina Bar association (Mar. 1989).

71. Federal Rules of Civil Procedure, 97 F.R.D. 165, $206-07$ (1983). 
relying entirely upon the reported decisions and commentaries. ${ }^{72}$ With the active collaboration of the chairman and reporters, the Columbia Project obtained foundation grants to support the research. In 1965 the research team delivered to the Advisory Committee an extensive report on the survey's findings. ${ }^{73}$ These findings disclosed that there were some similarities between the visible tip of the iceberg (the reported decisions and commentaries) and the underwater mass of discovery activity, but many discrepancies.

Social scientists teamed with lawyers in making the Columbia Project's field survey. Three specific research objectives were identified at the start of the work:

1. To produce a full description of the way federal discovery worked in practice throughout the nation, in law offices as well as in the courts;

2. To determine the impact of discovery on the litigation process; and

3. To learn how the discovery rules interacted with other procedures and other rules. ${ }^{74}$

The Columbia team selected 1962 as the target year for the survey work. In-depth interviews of lawyers on both sides of a systematically drawn sample of 500 terminated cases were completed in six selected districts. A second sample of about 900 cases was drawn from thirty-seven additional districts in order to broaden the base and survey as much of the federal practice throughout the country as feasible. In all, the interviews and questionnaires produced about 2000 sets of responses relating to approximately 1200 cases. ${ }^{75}$

The project also conducted a complete search of all reported decisions on pretrial discovery during a three-and-a-half-year span from 1960 to 1964 , analyzed the cases, and compared the results with the data from the field survey. ${ }^{76}$

The Advisory Committee, in a preamble to its proposed 1970 amendments to the discovery rules, summarized several of the survey's major findings:

The Columbia Survey concludes, in general, that there is no empirical evidence to warrant a fundamental change in the philosophy of the discovery rules. No widespread or profound failings are disclosed in the scope or availability of discovery. The costs of discovery do not appear to be oppressive, as a general matter, either in relation to ability to pay or to the stakes of the litigation. Discovery frequently provides evidence that would not otherwise be available to the parties and thereby makes for a fairer trial or settlement. On the other hand, no positive evidence is found that discovery promotes settlement. ${ }^{77}$

72. Rosenberg, Changes Ahead in Federal Pretrial Discovery, 45 F.R.D. 479, 482 (1969).

73. Columbia University Project for Effective Justice, Field Survey of Federal Pretrial Discovery (Nov. 1964) (unpublished report).

74. Id. at I- 1 .

75. Rosenberg, supra note 72 , at 483 .

76. The major findings of the discovery survey are reported in Rosenberg, supra note 72 , at 479 ; see also W. Glaser, Pretrial Discovery and the Adversary System (1968).

77. Glaser, Proposed Amendments to the Federal Rules of Civil Procedure Relating to Discovery, 48 F.R.D. $487,489-90(1970)$. 
Several of the 1970 changes in the discovery rules expressly relied upon specific findings of the Columbia survey. For instance, in explaining its substantial overhaul of the procedures in Rule 33 governing written interrogatories by parties, the Advisory Committee accepted the survey's finding that interrogatories were the breeding ground for more objections than any other discovery instrument, and that the existing procedures stimulated motions the court was obliged to decide. ${ }^{78}$ Eliminating the necessity to file a motion with the court under Rule 34 for an order permitting inspection of documents or things is another example of a major rule change prompted by survey findings. ${ }^{79}$ The Advisory Committee's proposal for dealing with the race for priority in discovery was also based on data from the field. ${ }^{80}$

Possibly as important as the changes made in reliance on the empirical findings were changes not made (although suggested and considered) because the findings from the field did not give evidence of a need for them.

In soliciting and utilizing empirical data as a predicate for reforming the federal discovery rules the Advisory Committee blazed an important path. It has trod that path several times since the 1960's, convinced that polemics, argument, and judicial opinions are quite incomplete without the complement of empirical research. Today, the lively debate in the country over the impact of the 1983 amendments to Rule 11 is not limited to dialectics: Data derived from empirical research are the favored weapons. ${ }^{81}$

78. The Advisory Committee's Note declared:

The mechanics of the operation of Rule 33 are substantially revised by the proposed amendment, with a view to reducing court intervention .... The Columbia survey shows that, although half of the litigants resorted to depositions and about one-third used interrogatories, about 65 percent of the objections were made with respect to interrogatories and 26 percent related to depositions .... The procedures now provided in Rule 33 seem calculated to encourage objections and court motions.

Id. at 522

79. The Advisory Committee's Note declared:

The revision of Rule $\mathbf{3 4}$ to have it operate extrajudicially, rather than by court order, is to a large extent a reflection of existing law office practice. The Columbia survey shows that of the litigants seeking inspection of documents or things, only about 25 percent filed motions for court orders .... Although an extrajudicial procedure will not drastically alter existing practice under Rule 34-it will conform to it in most cases-it has the potential of saving court time in a substantial though proportionately small number of cases tried annually.

Id. at 527 .

80. See id. at 506.

81. Even a partial list of major surveys illustrates what change has come about in the process of federal rulemaking. See Report of the Third Circuit Task force on Federal Rule of Civil Procedure 11 (1988); T. Willging, The Rule 11 Sanctioning Process (1989); S. Kassin, An Empirical Study of Rule 11 Sanctions (1985); New York State Bar ass'n, Report of the Committee on Federal Courts: Sanctions and Attorneys' Fees (1987); Vairo, Report to the Advisory Committee on Amended Rule 11 of the Federal Rules of Civil Procedure (unpublished manuscript 1987); Nelken, Sanctions Under Amended Federal Rule 11-Some "Chilling "Problems in the Struggle Between Compensation and Punishment. 74 Geo. L.J. 1313, 1325-38 (1986). 
$\mathrm{X}$

Non-experimental Research: Judicial Usage

Procedural reform comes about in the greatest part by legislation or legislative-style rulemaking. It is therefore to be anticipated that the impact of empirical research on judicially declared procedural reforms will be less evident, and that is the case. In Colgrove v. Battin, the Supreme Court upheld the validity of a local rule of the United States District Court for Montana reducing the size of civil juries from twelve to six persons. ${ }^{82}$ Williams $v$. Florida ${ }^{83}$ which had sustained six-person juries in criminal cases, preceded Colgrove by three years. The Williams court took note of empirical studies reporting that there is no significant difference in the functioning of the sixperson as opposed to twelve-person jury. ${ }^{84}$ The Colgrove court declared that "four very recent studies have provided convincing empirical evidence of the correctness of the Williams conclusion that 'there is no discernible difference between the results reached by the two different-sized juries." "85

Once the legality of the reduction of civil juries to six persons was upheld, other districts followed Montana. Today all but a handful of the federal district courts use the six-person jury routinely in civil trials. ${ }^{86}$ During the decade after the Colgrove decision, numerous scholars commented-critically, for the most part-on the Supreme Court's use of social science data in the jury-size cases. ${ }^{87}$ Many predicted that there would be dire effects upon the functioning of federal civil juries. ${ }^{88}$ To date, these seem not to have materialized. A feasible and useful investigation would be to compare the performance of the different-sized juries. If there are gross differences between the smaller and the larger panels, they should turn up in carefully conducted research programs. Side-by-side and before-and-after studies, complemented by archival investigations and surveys of lawyers' views and experiences, would doubtless shed much light upon the impact of downsizing the jury. Also, direct comparisons of functioning and outcomes can be made in actual trials by empaneling shadow juries of the "other" size.

Another example of a court's use of empirical data to determine the impact of a contemplated rule in the context of judicial administration reform is Kirby $v$. Larson. ${ }^{89}$ The issue before the Michigan Supreme Court was whether state law should shift from contributory negligence to comparative negligence by judicial decision. One factor of significance was the potential

82. 413 U.S. $149,149-51$ (1973).

83. 399 U.S. 78 (1970).

84. Id. at 101 .

85. 413 U.S. at 159 n.15.

86. Administrative Office of the United States Courts, 1987 Grand and Petit Juror Service in United States District Courts 129-36 (1987).

87. See, e.g., Zeisel \& Diamond, "Convincing Empirical Evidence" on the Six Member Jury, 41 U. CH1. L. Rev. 281 (1974); see also Ballew v. Georgia, 435 U.S. 223, 213 n.10 (1977) (listing a considerable quantity of scholarly work on jury size).

88. See, e.g., Zeisel \& Diamond, supra note 87, at 292-95.

89. 400 Mich. 585, 613-25, 642-59 (1977). 
impact on the dockets of a switch to comparative negligence. In an appendix to its opinion, the court looked closely at the results of two field studies reporting on the impact of the adoption of comparative negligence in Arkansas.90 One study was done by the Columbia Project shortly after Arkansas had shifted to comparative negligence in 1957.91 Ten years later the Arkansas Law Review replicated the study using the same form of questionnaire and obtained virtually identical results. ${ }^{92}$

Using the Arkansas studies, the Supreme Court of Michigan reported that it was satisfied that the impact of shifting to comparative negligence had not been to overwhelm the courts in that state and that it expected no different effect in Michigan. ${ }^{93}$ The court felt free to adopt the comparative negligence rule on substantive grounds. ${ }^{94}$

\section{$\mathrm{XI}$}

\section{Strengthening Procedure-Impact Research}

There are many ways to increase the influence and utility of procedural impact studies. Today, one of the chief problems in getting lawmakers, be they courts, legislatures, or rulemakers, to accept and use social science is the tendency of investigators to pick research targets that are so broad, amorphous, and value-drenched that they become easy marks for rejection. If, instead of choosing a blockbuster topic, the research team takes on a more modest issue, especially one the legislature or the court is due to have on its agenda for action or decision, the findings are much more likely to be treated with respect. This is not a plea for investigation of the trivial or inconsequential. Rather, it is a suggestion that much effective research needs to be done on front-burner subjects in the area Harry Kalven has called the "middle range."95

Experience in reporting findings to procedural revisers and rulemakers teaches a sobering lesson: Persuading them to accept empirical research results will be a formidable task even if the research speaks directly to precisely defined and topical questions. Data have great trouble piercing made-up minds. Some judges and lawyers believe there are only two kinds of research findings: those they intuitively agree with ("That's obvious!"); and those they intuitively disagree with ("That's wrong!"). Resistance to the counterintuitive is a formidable barrier to the acceptability of procedureimpact research findings.

90. Id. at 648-51.

91. Rosenberg, Comparative Negligence in Arkansas: A "Before and After" Survey. 13 ARK. L. REv. 89 (1959).

92. Note, Comparative Negligence-A Survey of the Arkansas Experience, 22 Ark. L. REv. 692 (1969). This rare instance of a follow-up study in the field of legal impact represents a valuable product that is in short supply in law-related research. Cf. supra note 27.

93. Kirby, 400 Mich. at 651 .

94. Id.

95. Kalven, The Quest for the Midale Range: Empirical Inquiry and Legal Poliry, in Law in a CHanginG AMERICA 56 (G. Hazard ed. 1968). 


\section{XII}

\section{Conclusion}

There is no claim here that the examples of procedure-impact research discussed in this paper are exhaustive or representative. They do not cover the large body of research on court delay and congestion or studies of the jury's comprehension of instructions and other investigations of issues related to jury functioning, apart from the issue of jury size. I have tried to address here studies of which I am aware that have had a significant or, at least, discernible, impact on reform in procedural law.

Despite serious obstacles, the influence of empirical research on procedural reform is destined to grow. A vast range of interesting and significant subjects await attention. Some of these are, to my mind, so basic to improvement and so much needed that the day must come soon when serious investigations of them will be undertaken. These are examples of what we need to know:

1. What percentage of the cases that come to judicial attention are adjudicated, either by trial or on motion? It is astonishing that there can be such wide differences of opinion on this question, but the fact is that no one has made a useful study-at least for the federal courts-of the proportion of cases that are adjudicated other than by trial.

2. Why, in the federal courts, have appeals been climbing at about twice the rate of increase of district court terminations?

3. To what extent is the appellate workload increase exacerbated by appeals filed due to inconsistency, vagueness, or similar flaws in the appellate courts' decisions?

4. What is the impact of Rule 11? There are many efforts to gauge the effect of Rule 11 on civil litigation practices, but no study has yet gotten to the bottom of the issue.

5. How much does discovery cost? A large part of the expense of significant lawsuits goes to pay for pretrial discovery. We need to know more particulars about costs of discovery, including what factors correlate with greater or lesser cost.

6 . What is the differential influence of diverse forms of standard instructions on the jury's comprehension and application of the law? 7. What is the impact of various court-annexed alternative dispute resolution methods other than arbitration (for example, summary jury trials, minitrials, and mediation) on the quantity of judicial work and the quality of the judicial process?

These and many other issues await illumination by serious empirical research. They are all high on the civil procedure need-to-know list. 